\title{
The Inhibitory Effect of Natural Stilbenes and Their Analogues on Catalytic Activity of Cytochromes P450 Family 1 in Comparison with Other Phenols - Structure and Activity Relationship
}

\author{
Renata Mikstacka ${ }^{1}$, Zbigniew Dutkiewicz ${ }^{1}$, \\ Stanisław Sobiak ${ }^{1}$ and Wanda Baer-Dubowska ${ }^{2}$ \\ ${ }^{1}$ Departament of Chemical Technology of Drugs, Poznan University of Medical Sciences \\ ${ }^{2}$ Department of Pharmaceutical Biochemistry, Poznań University of Medical Sciences
}

Poland

\section{Introduction}

In the last decade, increasing interest in the role of nutrition in disease prevention has been observed. The World Health Organization (WHO) reported that one-third of all cancer deaths could be prevented, and that diet plays a key role in prevention (Bode \& Dong, 2009). The term chemoprevention introduced and developed by Sporn (2005) and Wattenberg (1985) refers in general to multi-targeted pharmacological and nutritional intervention with the use of naturally occurring or chemically synthesized compounds. For this purpose, dietary phytochemicals believed to be safe for human use seem to be very promising. The importance of natural chemopreventive agents relies on their non-toxicity when given in small amounts for longer periods of time. Moreover, using a combination of phytochemicals provides synergistic or additive preventive effects.

Cancer cell growth arises through a complex multistep process by which cancer cells acquire characteristics of unlimited proliferation potential, lack of response to growth signals, and resistance to cell death. Thus, preventive/therapeutic action of phytochemicals may be directed towards numerous molecular targets that are proteins involved in procarcinogen metabolism, cell transformation and proliferation, and signaling pathways leading to apoptosis of damaged or transformed cells (William et al., 2009). Targeting enzymes of the P450 superfamily may provide one of the strategies for enhancing the efficacy of chemopreventive and therapeutic agents (Swanson et al., 2010).

Mechanistic studies of natural compounds are of great value regarding their characteristics of bioactivity, efficacy, selectivity and potential adverse side effects. Targeted inhibition of metabolic activation of carcinogens and induction of detoxifying enzymes has been considered a fundamental strategy for blocking the early stage of carcinogenesis. For example, inhibition of CYP1 enzymes was one test in the battery of assays employed in 
screening of potential cancer chemopreventive agents (Gerhauser et al., 2003). Variable dietary exposure to phytochemicals may contribute to some of the inter-individual variation in the pharmacokinetics and pharmacological responses that are observed for drugs such as phenacetin, caffeine, and theophylline, which are substrates for CYP1A2 (Rendic \& Di Carlo, 1997). Further research is needed to determine the extent to which the effect of dietary exposure may be modified by genetic polymorphism of xenobiotic metabolizing enzymes.

Phenolics are a diverse group of aromatic compounds broadly distributed in plants. Among this group, stilbenoids are compounds displaying multiple activities of interest with regard to cancer prevention and therapy, and their anticancer properties have been proven in various animal models (Szekeres et al., 2010). In this review, we summarize the results of studies on inhibitory activity of trans-resveratrol (3,4',5-trimethoxy-trans-stilbene), the best recognized trans-stilbene (Figure 1), and its natural and synthetic analogues toward expression and activity of CYPs responsible for procarcinogen activation. We discuss the role of cytochrome family 1 inhibitors in cancer chemoprevention and chemotherapy. Additionally, we compare their effect with other natural phenols occurring in plant foods in relatively high amount and exerting significant bioactivity. Finally, we analyze the use of computational methods for biomolecular docking in structure and activity relationship studies of CYP1 inhibitors.<smiles>[R20]c1cc([R20])cc(/C=C/c2ccc([R20])c([R3])c2)c1</smiles>

$\begin{array}{llllll}\text { 1. } & & \mathrm{R}_{1} & \mathrm{R}_{2} & \mathrm{R}_{3} & \mathrm{R}_{4} \\ \text { 2. } & \text { Piceatannol } & \mathrm{H} & \mathrm{H} & \mathrm{H} & \mathrm{H} \\ \text { 3. } & \text { Rhapontigenin } & \mathrm{H} & \mathrm{H} & \mathrm{OH} & \mathrm{H} \\ \text { 4. } & \text { Desoxyrhapontigenin } & \mathrm{H} & \mathrm{H} & \mathrm{OH} & \mathrm{CH}_{3} \\ \text { 5. } & \text { Pinostilbene } & \mathrm{H} & \mathrm{H} & \mathrm{H} & \mathrm{CH}_{3} \\ \text { 6. } & \text { Pterostilbene } & \mathrm{H} & \mathrm{CH}_{3} & \mathrm{H} & \mathrm{H} \\ & & \mathrm{CH}_{3} & \mathrm{CH}_{3} & \mathrm{H} & \mathrm{H}\end{array}$

Fig. 1. Structure of trans-resveratrol and its natural analogues

\section{Potential strategies targeting CYPs for cancer therapy and prevention}

One of the strategies of cancer chemoprevention is directed at drug-metabolizing enzymes such as cytochromes P450 (CYPs), a superfamily which metabolizes a wide spectrum of endogenous and exogenous substrates. Cytochrome P450 family 1 comprises three important isoforms: CYP1A1, CYP1A2 and CYP1B1 that catalyze the activation of procarcinogens such as polycyclic aromatic hydrocarbons, and aromatic and heterocyclic 
amines. Additionally, CYP1B1 metabolizes 17ß-estradiol (E2) to 4-hydroxyestradiol (4-OHE2), which is further oxidized by peroxidase to estradiol-3,4-quinone to form a quinoneDNA adducts responsible for estrogen-related carcinogenesis (Liehr et al., 1996). This pathway of metabolism is extensively studied with respect to polymorphism of CYP1 enzymes and its association with carcinogenic metabolite formation (Kisselev et al., 2005).

All members of the human CYP1 family are expressed in extrahepatic tissues. However, CYP1A2 is the only constitutive form of liver enzyme, and as such takes part in metabolism of xenobiotics, including numerous drugs (caffeine, theophylline, methadone, verapamil, propranolol, warfarin, tamoxifen). On the other hand, it is worth mentioning that microbial CYPs are considered as drug targets and may be used as biocatalysts in drug biosynthesis (Lamb et al, 2007).

In humans, CYP1B1 is overexpressed in tumor cells, and this has important implications for tumor development and progression (Castro et al., 2008). It was found that CYP1B1 knockout mice were highly resistant to 7,12-dimethylbenz[a]anthracene induced tumor formation (Gonzalez, 2002). Thus, regulators of the expression and catalytic activity of family 1 cytochromes appear to play an important role in cancer chemoprevention by blocking the initial stages of tumorigenesis. With respect to cancer chemotherapy, CYP1A1 and CYP1B1 have the ability to metabolize cytostatics, diminishing their toxic effect on cancer cells (McFadyen \& Murray, 2001). Considering this, the inhibition of CYP1B1, an enzyme up-regulated in many cancers, would be a strategy to prevent the loss of cytostatics effectiveness. On the other hand, the development of anticancer prodrugs specifically activated by CYP1B1 to cytotoxic compounds might be a promising novel strategy in cancer chemotherapy (Bruno \& Njar, 2007).

\section{Mechanism of the expression of CYP1 genes - AHR as a target for effective chemopreventive approach}

Members of the CYP1 family are under the transcriptional control of the aryl hydrocarbon receptor (AHR) localized in cytosol that is activated by polyhalogenated aromatic hydrocarbons, among them 2,3,7,8-tetrachlorodibenzo-p-dioxin (TCDD). AHR agonists are well known environmental pollutants. As a result of activation AHR translocates into the nucleus and forms a dimer with ARNT (aryl hydrocarbon nuclear translocator). The AHR/ARNT complex is characterized by a high affinity to specific DNA recognition sites termed DREs (dioxin response elements) or AHREs (aryl hydrocarbon response element) which upregulate a battery of target genes, including those involved in metabolism of chemical carcinogens such as CYP1A1, CYP1A2 and CYP1B1 (Fig. 2). In this way, agonists induce the expression of xenobiotic metabolizing enzymes (XMEs) that activate procarcinogens to genotoxic forms. Thus, the treatment with AHR antagonists by preventing this undesirable effect might be a chemopreventive strategy.

There are phytochemicals that possess the ability to block agonist interaction with the ligand-binding site of the AHR and agonist induction of the AHR-signaling pathways. In that respect, resveratrol is the best recognized stilbene derivative. Moreover, it is one of the best-characterized chemopreventive phytochemicals (Goswami and Das, 2009). It occurs mainly in small fruits like berries and grapes, peanuts and red wine. Its chemopreventive properties found in studies on animals in vivo were described for the first time by Jang and 


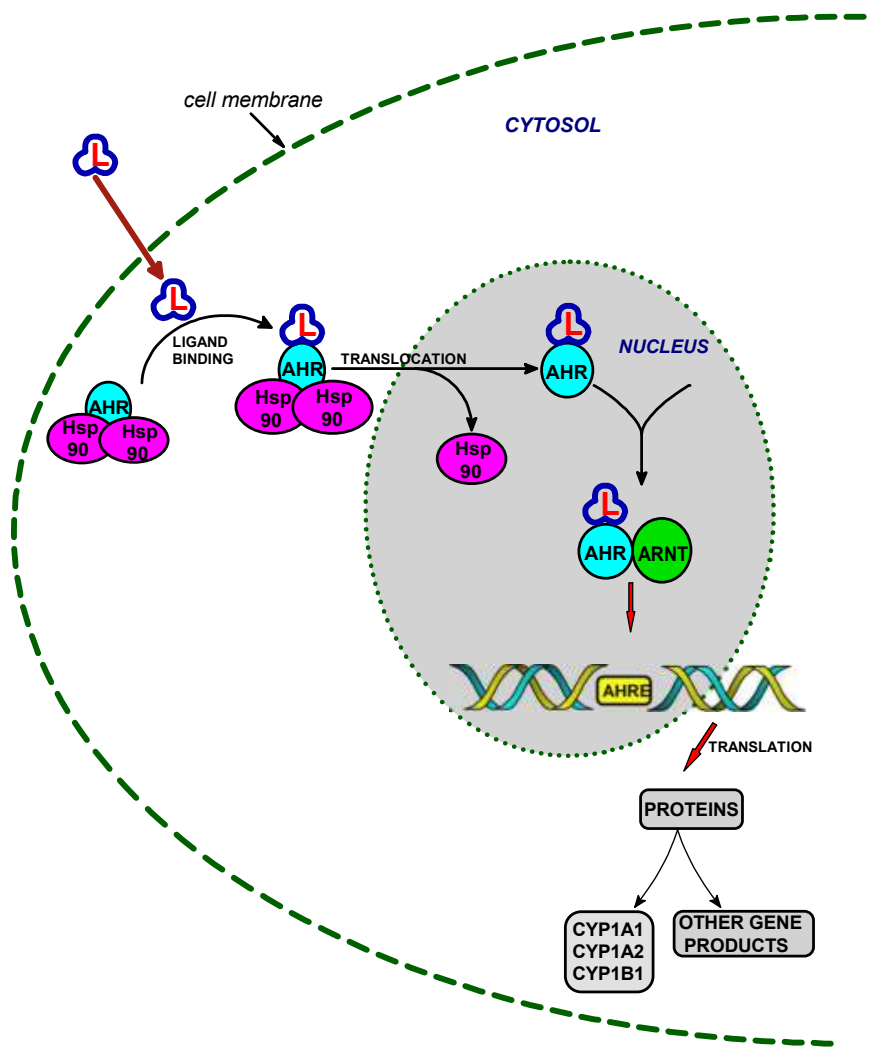

Fig. 2. AHR signaling pathway; L - ligand; Hsp90 - heat shock protein 90; ARNT - aryl hydrocarbon nuclear receptor; AHRE - aryl hydrocarbon response element. AHR/ARNT complexes bind to the DNA recognition sequence AHRE located in regulatory regions of phase I (CYP1A1, CYP1A2, CYP1B1) and phase II drug metabolizing enzymes.

coworkers (Jang et al., 1997). Chen and collaborators have reported that resveratrol strongly inhibited TCDD-induced AHR binding activity in human mammary epithelial (MCF-1-A) cells (Chen et al., 2004). The inhibition of CYP1A1 expression by resveratrol was observed in rat primary hepatocytes (Andrieux et al., 2004). In human HepG2 hepatoma cells, resveratrol inhibited the increase in CYP1A1 mRNA caused by TCDD in a concentrationdependent manner. The induction of transcription of an aryl hydrocarbon-responsive reporter vector containing the CYP1A1 promoter by TCDD was likewise inhibited by resveratrol. Resveratrol also inhibited the constitutive level of CYP1A1 mRNA and reporter vector transcription in human hepatoma HepG2 cells (Ciolino et al., 1998). Resveratrol was also effective in inhibiting CYP1A1 transcription induced by the aryl hydrocarbon dimethylbenz[a]anthracene in human mammary carcinoma MCF-7 cells and B[a]P-treated HepG2 cells (Ciolino et al., 1999). These data demonstrate that resveratrol inhibits aryl hydrocarbon-induced CYP1A activity in vitro by directly inhibiting CYP1A1/1A2 enzyme activity, and by inhibiting the signal transduction pathway that up-regulates the expression of carcinogen activating enzymes. The antagonistic action of resveratrol was supported by in 
vivo experiments on phytochemicals with four different structures, where only resveratrol given topically on mouse epidermis inhibited aryl hydrocarbon hydroxylase (AHH) activity in a dose dependent manner (Table 1) (Szaefer et al., 2004). Moreover, resveratrol has been shown to prevent genotoxicity of B[a]P by inhibiting B[a]P-induced CYP1A1 expression and BPDE-DNA adduct formation in the lungs of mice (Revel et al., 2003).

\begin{tabular}{|l|c|c|}
\hline \multicolumn{1}{|c|}{ Treatment } & Dose & $\begin{array}{c}\text { Activity [pmol/min/mg } \\
\text { protein] }\end{array}$ \\
\hline Acetone & $0.2 \mathrm{ml}$ & $65.3 \pm 4.6$ \\
\hline 5,6-Benzoflavone & $8 \mu \mathrm{M}$ & $336 \pm 17.2$ \\
\hline Protocatechuic acid & $8 \mu \mathrm{M}$ & $75.3 \pm 2.1$ \\
& $16 \mu \mathrm{M}$ & $83.4 \pm 6.4$ \\
\hline Chlorogenic acid & $8 \mu \mathrm{M}$ & $71.7 \pm 3.2$ \\
& $16 \mu \mathrm{M}$ & $83.9 \pm 2.8$ \\
\hline trans-Resveratrol & $8 \mu \mathrm{M}$ & $18.9 \pm 2.6$ \\
& $16 \mu \mathrm{M}$ & $0.08 \pm 0.01$ \\
\hline
\end{tabular}

Table 1. Effect of phenolic compounds on mouse epidermal AHH activity

Summarising, resveratrol inhibits AHR-dependent transcription by preventing AHR/ARNT binding to the AHRE. The activity of preventing the conversion of ligand-bound cytosolic AHR into its nuclear DNA-binding form and/or the interaction between the AHR and the transcription initiation complex at the CYP1A1 gene promoter may be an important part of the chemopreventive activity of resveratrol. However, the action of resveratrol is not specific because this natural stilbene as a phytoestrogen is also a potent ER (estrogen receptor) agonist. Recently, experiments on human breast cancer cells revealed that the estrogenic properties of resveratrol and its influence on the ER expression are independent of its ability to inhibit the expression of genes controlled by AHR (MacPherson \& Matthews, 2010). New stilbene derivatives of resveratrol that were synthesized appeared to be selective for AHR and devoid of affinity for ER. Among the trans-stilbenes synthesized, all displayed a significantly higher affinity than resveratrol for AHR. Substitution of 3- and/or 5-hydroxy groups with chlorine atoms coupled with replacement of 4'-hydroxy with chlorine or a methoxy group yielded selective TCDD antagonists with high affinity for the AHR that was much higher than resveratrol. Interestingly, one of the studied compounds, 3-hydroxy-5chloro-4'-trifluoromethyl-trans-stilbene, was a selective AHR agonist exerting extremely high-affinity to AHR with a $\mathrm{K}_{\mathrm{i}}$ of $0.2 \mathrm{nM}$. None of the compounds studied showed any detectable affinity for the ER that should eliminate estrogen-related risks, such as the increased risk of ER-related cancers (de Medina et al. 2005).

In the Table 2 we summarized the studies on the effects of resveratrol and its derivatives on AHR related expression of CYP1 enzymes. However, the results of in vivo experiments on animals are highly dependent on the dose of a studied compound, as well as the duration and manner of its administration. Further, the effect of a studied substance may also be tissue-dependent. The expression of CYP1A1 and CYP1A2-related monooxygenases in hepatic subcellular preparations from resveratrol treated male mice did not differ from the control; while in pulmonary subcellular preparations significantly lower expression of CYP1A1/2 -dependent enzymes was observed (Canistro et al., 2009). 


\begin{tabular}{|c|c|c|c|}
\hline Effect & Compound & Experimental Model & References \\
\hline $\begin{array}{l}\text { AHR translocation } \uparrow \\
\text { AHRE transactivation } \downarrow\end{array}$ & resveratrol & $\begin{array}{l}\text { 47DRE reporter cell } \\
\text { line }\end{array}$ & Casper et al., 1999 \\
\hline $\begin{array}{l}\text { AHR DNA binding } \downarrow \text {, } \\
\text { expression and activity of } \\
\text { CYP 1A1/1B1 } \downarrow\end{array}$ & resveratrol & $\begin{array}{l}\text { TCDD-treated MCF- } \\
\text { 10A cells }\end{array}$ & Chen et al, 2004 \\
\hline $\begin{array}{l}\text { Expression and activity of } \\
\text { CYP1A1/1A2 } \downarrow\end{array}$ & resveratrol & $\begin{array}{l}\mathrm{B}[\mathrm{a}] \mathrm{P} \text {-treated HepG2 } \\
\text { cells and DMBA- } \\
\text { treated MCF-7 cells }\end{array}$ & Ciolino et al., 1999 \\
\hline $\begin{array}{l}\text { CYP1A1 expression } \downarrow \\
\text { Induction of transcription of } \\
\text { AHR reporter vector } \\
\text { containing the CYP1A1 } \\
\text { promoter by TCDD } \downarrow \\
\text { constitutive level of CYP1A1 } \\
\text { mRNA and reporter vector } \\
\text { transcription } \downarrow\end{array}$ & resveratrol & $\begin{array}{l}\text { TCDD treated human } \\
\text { HepG2 cells }\end{array}$ & Ciolino et al., 1998 \\
\hline $\begin{array}{l}\text { CYP1A1 expression } \downarrow \\
\text { BPDE-DNA adduct } \\
\text { formation } \downarrow\end{array}$ & resveratrol & $\begin{array}{l}\text { lung tissue from BP- } \\
\text { treated mice }\end{array}$ & Revel et al., 2003 \\
\hline $\begin{array}{l}\text { CYP1A1 expression by } \\
\text { resveratrol } \downarrow\end{array}$ & resveratrol & $\begin{array}{l}\text { rat primary } \\
\text { hepatocytes }\end{array}$ & $\begin{array}{l}\text { Andrieux et al., } \\
2004\end{array}$ \\
\hline $\begin{array}{l}\text { AHR binding ability of } \\
\text { resveratrol and its } \\
\text { derivatives } \downarrow\end{array}$ & $\begin{array}{l}\text { resveratrol and } \\
24 \text { other } \\
\text { stilbenes }\end{array}$ & $\begin{array}{l}\text { 47DRE reporter cell } \\
\text { line }\end{array}$ & $\begin{array}{l}\text { de Medina et al., } \\
2005\end{array}$ \\
\hline $\begin{array}{l}\text { Expression of human } \\
\text { CYP1A1 and CYP1B1 } \downarrow \\
\text { Recruitment of the AHR } \\
\text { complex and RNA } \\
\text { polymerase II to the } \\
\text { regulatory regions } \downarrow\end{array}$ & resveratrol & $\begin{array}{l}\text { TCDD-induced } \\
\text { human breast cancer } \\
\text { cell line MCF-7, and } \\
\text { human hepatocellular } \\
\text { carcinoma cell line, } \\
\text { HepG2 }\end{array}$ & $\begin{array}{l}\text { Beedanagari et al., } \\
2009\end{array}$ \\
\hline $\begin{array}{l}\text { AHR-dependent } \\
\text { transcription of CYP1A1 } \\
\text { and CYP1B1 } \downarrow\end{array}$ & resveratrol & $\begin{array}{l}\text { TCDD-induced } \\
\text { human breast cancer } \\
\text { cells T-47D }\end{array}$ & $\begin{array}{l}\text { MacPherson and } \\
\text { Matthews, } 2010\end{array}$ \\
\hline $\begin{array}{l}\text { CYP1A1 and CYP1B1 } \\
\text { expression } \downarrow \\
\text { Recruitment of AHR and } \\
\text { ARNT to CYP1A1 and } \\
\text { CYP1B1 enhancer regions } \downarrow\end{array}$ & piceatannol & $\begin{array}{l}\text { TCDD-induced } \\
\text { human breast cancer } \\
\text { cells T-47D }\end{array}$ & $\begin{array}{l}\text { MacPherson and } \\
\text { Matthews, } 2010\end{array}$ \\
\hline
\end{tabular}

Table 2. AHR as a molecular target for chemopreventive action of resveratrol and its derivatives 


\section{Inhibitory effect of stilbene derivatives on CYP1A enzymes}

\subsection{Trans-resveratrol}

The studies of the inhibitory effect of phytochemicals on cytochrome P450 dependent enzymes are mainly conducted with the use of in vitro techniques on cDNA-expressed enzymes. Recombinant biscistronic supersomes express particular CYP activity and cytochrome c reductase activity. It was reported that resveratrol inhibited human recombinant P450 1A1 activity in a competitive manner (Chun et al., 1999), but the $\mathrm{IC}_{50}$ value (the concentration that causes $50 \%$ inhibition of enzyme activity) of $23 \mu \mathrm{M}$ was much higher than the $\mathrm{IC}_{50}$ value of $1.4 \mu \mathrm{M}$ obtained for CYP1B1 inhibition (Chang et al., 2000). Interestingly, resveratrol inactivated human recombinant CYP1A2 indirectly in a mechanism-based manner (Chang et al, 2001).

Mechanism-based inhibition was not observed in rat liver microsomes; EROD (7ethoxyresorufin-O-deethylase) activity as an indicator of both CYP1A1 and CYP1A2 was inhibited by resveratrol and piceatannol $\left(3,3^{\prime}, 4,5^{\prime}\right.$-tetrahydroxy-trans-stilbene) with $K_{i}$ value of $0.4 \mu \mathrm{M}$ for both compounds and a mixed type of inhibition (Chang et al., 2007). It was found that resveratrol is metabolized to piceatannol in the reaction of hydroxylation catalyzed by CYP1A2 (Piver et al. 2004) and CYP1B1 (Potter et al. 2002). Poor bioavailability of resveratrol caused by its fast metabolism to glucuronides and sulphates limits the use of this stilbene as a potent chemopreventive / chemotherapeutic agent (Walle et al., 2004). To explain the bioactivity of resveratrol, its accumulation to active levels in target organs or synergistic / additive effects with other food components are taken into account.

\subsection{Natural resveratrol analogues}

During the last decade, other naturally occurring stilbenoid compounds with potential health benefit were found and examined. Piceatannol and pterostilbene (3,5-dimethoxy-4'hydroxy-trans-stilbene) occur mainly in grapes and blueberries, with their amount depending on plant variety (Rimando et al., 2004). Pterostilbene that was shown to have cancer chemopreventive activity similar to resveratrol (Rimando et al., 2002) occurs also in some medicinal plants used in traditional medicine. Beneficial bioactivity of natural resveratrol analogues have been demonstrated in numerous in vitro experiments and in preclinical animal models (Rimando and Suh, 2008). Resveratrol analogues exert multiple bioactivities involved in cancer chemoprevention; for example, they are efficient inhibitors of family 1 cytochromes. The inhibitory action of natural stilbenes appears to be highly selective depending on the cytochrome isoform. Moreover, the extent of CYP inhibition changes according to the stilbene structure; the types and positioning of functional groups linked to the stilbene scaffold significantly influence inhibitory activity of stilbene derivatives. Rhapontigenin (3,5,3'-trihydroxy-4'-methoxystilbene) was found to be a very selective and potent inactivator of CYP1A1 activity with $\mathrm{IC}_{50}$ value $0.4 \mu \mathrm{M}$ and $\mathrm{K}_{\mathrm{i}}$ value of $0.09 \mu \mathrm{M}$ (Chun et al., 2001a). Pinostilbene (3,4'-dihydroxy-5-methoxy-trans-stilbene), pterostilbene and desoxyrhapontigenin (3,5-dihydroxy-4'-methoxy-trans-stilbene) were more efficient inhibitors of CYP1A1 and CYPA2 in comparison to the parent compound, while they inhibited CYP1B1 to the same extent as resveratrol (Guengerich et al., 2003; Mikstacka et al., 2006, 2007). The data on the inhibition of CYP1 enzymes by natural stilbenes are summarized in Table 3. 


\subsection{Resveratrol methyl ethers and other synthetic stilbenes}

In the last decade, new stilbene derivatives have been designed and synthesized in order to find more potent chemopreventive agents (Szekeres et al., 2010). The additional aim of this approach was to find resveratrol derivatives demonstrating better bioavailability in comparison to the parent compound. The bioactivity of resveratrol analogues could be altered due to the presence and positioning of methoxy groups on the basic resveratrol backbone that prevent the conjugation reaction with sulphuric and glucuronic acids. Synthesized derivatives are tested with regard to their inhibitory activity toward CYP 1 enzymes in order to find more efficient and selective inhibitors. A series of trans-stilbene derivatives containing a 3,5-dimethoxyphenyl moiety were prepared and evaluated on human recombinant CYP1A, CYP1A2 and CYP1B1 to find a potent and selective CYP1B1 inhibitor. It was shown that substitution at the 2-position of the stilbene skeleton plays a very important role in discriminating between CYP1A1/2 and CYP1B1. Chun and his group found $3,5,2^{\prime}, 4^{\prime}$-tetramethoxy-trans-stilbene as a new selective and very potent inhibitor of human CYP1B1 (Chun et al., 2001b). Among the whole series of compounds tested, 3,5,2', $4^{\prime}-$ tetramethoxy-trans-stilbene exerted the most potent inhibitory activity toward CYP1B1 with an $\mathrm{IC}_{50}$ value of $2 \mathrm{nM}$. 2-[2-(3,5-dimethoxyphenyl)vinyl]tiophene showed comparable inhibitory activities, but its selectivity toward CYP 1B1 was lower (Kim et al. 2002).

Another series of stilbenes with 4-methylthiophenyl moiety were synthesized and their inhibitory potency toward human recombinant CYPs: CYP1A1, CYP1A2 and CYP1B1 was evaluated. Among compounds tested, 2-methoxy-4'-methylthio-trans-stilbene and 3methoxy-4'-methylthio-trans-stilbene demonstrated the most potent and selective inhibitory effect on CYP1A1 and CYP1B1 activities (Mikstacka et al, 2008).

\begin{tabular}{|l|l|l|l|l|l|l|}
\hline \multirow{2}{*}{ Compound } & \multicolumn{2}{|c|}{ CYP1A1 } & \multicolumn{2}{|c|}{ CYP1A2 } & \multicolumn{2}{|c|}{ CYP1B1 } \\
\cline { 2 - 7 } & $\begin{array}{c}K_{i} \\
{[\mu \mathrm{M}]}\end{array}$ & $\begin{array}{c}\text { Mode of } \\
\text { inhibition }\end{array}$ & $\begin{array}{c}K_{i} \\
{[\mu \mathrm{M}]}\end{array}$ & $\begin{array}{c}\text { Mode of } \\
\text { inhibition }\end{array}$ & $\begin{array}{c}K_{i} \\
{[\mu \mathrm{M}]}\end{array}$ & $\begin{array}{c}\text { Mode of } \\
\text { inhibition }\end{array}$ \\
\hline Resveratrol & $1.2^{\mathrm{a}}$ & mixed type & $\begin{array}{c}15.5^{\mathrm{a}} \\
5.33^{\mathrm{c}}\end{array}$ & mixed type & $0.75^{\mathrm{a}}$ & mixed type \\
\hline Piceatannol & 3.01 & competitive & $9.67 \mathrm{c}$ & mixed type & 0.27 & competitive \\
\hline Desoxyrhapontigenin & 0.16 & competitive & 1.04 & mixed type & 2.06 & competitive \\
\hline Pinostilbene & 0.13 & mixed type & 0.94 & mixed type & 0.90 & competitive \\
\hline Pherostilbene & 0.57 & competitive & $0.39 \mathrm{c}$ & mixed type & 0.91 & competitive \\
\hline
\end{tabular}

${ }^{a}$ Chang et al., 2001; ${ }^{b}$ Chun et al., 2001; c in mouse liver microsomes (Mikstacka et al., 2006); n.d. not determined

Table 3. Effect of natural trans-stilbenes on human recombinant CYP1A1, CYP1A2 and CYP1B1 activities 


\subsection{Other natural phenols}

The influence of other phenolic phytochemicals on CYP1 activities is worth presenting in the context of possible additive or synergistic effects of the micro-components of human diet. The properties of plant extracts rich in numerous bioactive substances are particularly interesting in terms of herb-drug interaction, which could be a subject of independent review. At the beginning of the last decade, Piver and collaborators (2003) discovered that non-volatile components of red wine or various Cognac beverages exert stronger inhibitory effect on CYP1A1, CYP1A2, and CYP1B1 than resveratrol and its dimer $\varepsilon$-viniferin. Another extract, prepared from the most widely used herbal medicine Ginkgo biloba, was tested for its ability to inhibit the major human cytochrome P450 enzymes (Gaudineau et al., 2004). It was demonstrated that the flavonoidic fraction of standardized extract inhibits human CYP1A2 and other cytochromes (CYP2C9, CYP2E1, and CYP3A4), wheras its terpenoidic fraction significantly inhibits only CYP2C9. In vivo CYP1A2 induction was observed as a result of herbal dietary supplementation (Rye et al., 2003). Effects of Cuban and Mexican herbal extracts used in traditional medicine (obtained from Heliopsis longipes, Mangifera indica L. and Thalassia testudinum) on CYP1A1/2 and other cytochromes involved in drug metabolism of CYP3A4 and CYP2D6 were studied with the use of human liver microsomes and compared with the pure constituents isolated from the extracts of affinin (an alkamide isolated from the $H$. longipes extract), $\mathrm{N}$-iso-butyl-decanamide, and mangiferin. The extracts significantly inhibited CYP1A1/2 activities, which reflects the high content of flavonoids with recognized CYP1A1/2 inhibitory properties (Rodeiro et al., 2009).

Numerous natural phenols demonstrate inhibitory activity toward CYP1 enzymes. Phytochemicals that exert inhibitory effects on CYP1A enzymes comparable to natural stilbenes comprise: flavonoids, isothiocyanates, coumarin and its derivatives.

Flavonoids represent a large class of phenolic phytochemicals. They are ubiquitously present in plant-derived foods and are important microcomponents of the human diet. Humans ingest approximately 0.6-1 g of these bioactive compounds daily (Kuhnau, 1976). The effects of flavonoids on CYP1 activities have been explored since the early nineties, including the effects of flavone and five hydroxylated derivatives on the methoxyresorufin O-demethylase activity catalyzed by human recombinant CYP1A1 and CYP1A2 (Zhai et al., 1998). The authors found galangin (3,5,7-trihydroxyflavone) as the most potent inhibitor of CYP1A2 with $\mathrm{K}_{\mathrm{i}}$ value of $8 \mathrm{nM}$. It should be mentioned that no stilbene derivative with a comparable inhibitory potency toward CYP1A2 was found. Furthermore, galangin showed almost 5-fold selectivity for CYP1A2 over CYP1A1; while, 7-hydroxyflavone exhibited 6-fold greater selectivity for CYP1A1 over CYP1A2. The other hydroxylated flavone derivatives: 3hydroxy; 5-hydroxy; 7-hydroxy- and 3,7-dihydroxyflavone were also potent inhibitors of CYP1A1 $\left(\mathrm{IC}_{50}<0.1 \mu \mathrm{M}\right)$ and CYP1A2 $\left(\mathrm{IC}_{50}<0.3 \mu \mathrm{M}\right)$.

In experiments with the use of human recombinant CYPs, seven flavonoids (myricetin, apigenin, kaempferol, quercetin, amentoflavone, quercitrin, and rutin) occurring in St. John's Wort were tested. They were found to be slightly more selective for CYP1B1 activity compared to CYP1A1. Apigenin and amentoflavone were competitive inhibitors of CYP1B1, while quercetin showed a mixed type of inhibition. The most potent CYP1B1 inhibitor was apigenin with $\mathrm{K}_{\mathrm{i}}$ of $60 \mathrm{nM}$. The same authors investigated CYP1 inhibition in cell system. Myricetin, apigenin, kaempferol and quercetin inhibited TCDD-induced EROD activity in 
intact 22Rv1 human prostate cancer cells. Because flavonoids were added 30 minutes prior to the EROD assay, the inhibition did not reflect down regulation of CYP1 mRNA or protein level (Chaudhary et al., 2006). The influence of flavonoid constituents of St. John's Wort were also studied by Schwarz's group. They demonstrated the differentiated inhibition of CYP1A1-catalyzed estradiol 2-hydroxylation according to CYP1A1 genotype. The variant CYP1A1.2 (Ile462Val) was significantly inhibited by quercetin, hypericin and pseudohypericin (naphthodiantrones), with $\mathrm{IC}_{50}$ values for 2-hydroxylation being more than two times lower than the wild-type enzyme. Additionally, the wild-type enzyme was efficiently inhibited by kaempferol, myricetin and resveratrol (Schwarz et al., 2011).

The synthesis of structures differentiated by type and positions of substituents leads to a continuation of structure and activity relationship (SAR) studies. Recently, Takemura and coworkers (2010) evaluated the structure-property relationship of 18 major flavonoids on inhibiting enzymatic activity of CYP1A1, 1A2 and 1B1 by using an ethoxyresorufin Odeethylation assay. Flavones and flavonols indicated relatively strong inhibitory effects on CYP1s compared with flavanone that does not have the double bond between Cpositions 2 and 3 on the C-ring. Flavonoids used in this study selectively inhibited CYP1B1 activity.

Special attention is paid to methoxy derivatives of flavone, which have inhibitory potency exceeding that of the parent compound (Walle \& Walle, 2007). In particular, methoxy types of flavones and flavonols such as chrysoeriol and isorhamnetin showed strong and selective inhibition against CYP1B1 (Takemura et al., 2010). The most potent inhibitors of CYP1 catalyzed ethoxyresorufin O-deethylation were the methoxylated flavones acacetin, diosmetin, eupatorin and the dihydroxylated flavone chrysin, indicating that the $4^{\prime}-\mathrm{OCH}_{3}$ group at the B ring and the 5,7-dihydroxy motif at the A ring play a prominent role in EROD inhibition (Androutsopoulos et al., 2011). It was observed that high metabolic turnover of methoxylated flavonoids may result in enhanced antiproliferative activity. Several flavonoid metabolites produced in reactions catalyzed by CYP1A1 or CYP1B1 have been shown to inhibit cancer cell cycle progression. The authors observed CYP1A1-catalyzed biotransformation of acacetin to luteolin, apigenin and scutellarein. The chemopreventive ability of these metabolites was previously established. Generally, it is suggested that dietary flavonoids exhibit three distinct modes of action with CYP1 enzymes: (1) inhibitors of CYP1 enzymatic activity, (2) CYP1 substrates and (3) substrates and inhibitors of CYP1 enzymes.

Coumarin (1,2-benzopyrone) and its derivatives occur naturally in several plant families. They are components of essential oils, and are often used as fragrance ingredients in human diet. Their effect on CYP1 activities have been studied since the early nineties. The naturally occurring coumarins: bergamotin, coriandrin, isoimperatorin, imperatorin, ostruthin are potent inhibitors of the metabolic activation of benzo(a)pyrene and dimethylbenzanthracene in the cell culture model system of mouse epidermis (Cai et al., 1997). In experiments in vitro, mechanism-based inactivation of hepatic EROD activity by natural coumarin coriandrin was observed (Cai et al., 1996). These results demonstrate that certain coumarins to which humans are exposed in their diet are bioactivated by CYP1A1 to reactive intermediates that subsequently form covalent adducts with the apoprotein, effectively destroying enzyme activity. 
Curcumin is a natural plant food additive obtained from turmeric used in spices and traditional Indian medicine. Its chemopreventive anticancer potential is well documented (Aggarwal et al., 2003). It belongs to hydroxycinnamic acid derivatives observed ubiquitously in plants. Earlier reports on the inhibition of rat liver microsomal CYPs by curcumin showed that curcumin is a strong inhibitor of CYP1A enzymes and CYP2B as well (Oetari et al., 1996; Thapliyal and Maru, 2001, 2003). However, these data were not confirmed in studies with human recombinant cytochrome P450s, where curcumin appeared to be a moderate inhibitor of CYP1A2 with $\mathrm{IC}_{50}$ value $40 \mu \mathrm{M}$ (Appiah-Opong et al., 2007). Appiah-Opong and coworkers synthesized curcumin derivatives that exhibited about 10- to 40-fold greater potency towards inhibition of CYP1A2 than curcumin itself (AppiahOpong et al., 2008).

Other natural phenols studied more recently with respect to CYP1 inhibition include phytocannabinoids, constituents of marijuana, and chromene amides from Amyris plumieri, a plant grown in the Caribbean, Central America and Venezuela used in folk medicine. Three major constituents in marijuana; $\Delta^{9}$-tetrahydrocannabinol, cannabidiol and cannabinol inhibited activities of human recombinant CYP1s: CYP1A1, CYP1A2 and CYP1B1 in a competitive manner (Yamaori et al., 2010). One of the amides (chromene acetamide) tested appeared to inhibit potently CYP1A1 activity in vitro with $\mathrm{IC}_{50}$ and $\mathrm{K}_{\mathrm{i}}$ values $1.547 \mu \mathrm{M}$ and $0.37 \mu \mathrm{M}$, respectively (Badal et al., 2011).

Interestingly, in the studies on different natural phenols Schwarz and Roots demonstrated that the inhibitory effect depends not only on the structure of the inhibitor, but also the substrate of the reaction catalyzed by CYPs used in the assay. They found flavonoids like myricetin, apigenin, quercetin, and kaempferol, as well as tea polyphenol (-)epigallo catechin gallate, strongly inhibited the formation of benzo(a)pyrene diolepoxide, the ultimate carcinogenic product of benzo(a)pyrene activation. Furthermore, resveratrol, an inhibitor of CYP1A1-catalyzed ethoxyresorufin deethylation, exhibited only slightly inhibitory effect on CYP1A1-mediated epoxidation of 7,8-diol-B(a)P (Schwarz \& Roots, 2003).

\section{Docking studies - The new approach to CYPs-phytochemical interaction}

Mechanistic studies of the inhibitory effect of stilbenes on enzyme activities are mainly conducted in vitro with the use of human recombinant cytochromes. However, the affinity of compounds to cytochromes may be determined by computational analysis of inhibitor/substrate docking in the enzyme active site. Molecular modeling is presumed to be helpful in predicting inhibitory potential of CYP regulators by characteristics of ligandenzyme interactions. We review in silico research on elucidating the mechanism of inhibitory action of phytochemicals by analysis of structure and activity relationship. Potential phytochemical candidates can be selected by in silico virtual screening, based on natural compound libraries (www.bioscreening.com). When active chemicals are selected, they may be "docked" into the target protein by using available programs, enabling detailed proteinligand interactions to be obtained and the best fit of a candidate compound to be identified. The main objective of molecular docking is to determine the binding interactions between protein and ligand. 
Computational procedures of molecular modeling have been employed since the nineties. Studies of Lewis and coworkers (1997) on CYP1 family enzymes structure and ligand docking in enzyme cavities have been a great contribution to the development of this field. Lewis formulated the general characteristic of CYP1 ligands as planar and polar polycyclic molecules. Substituents linked to the polycyclic hydrocarbon core influence the ligand binding responsible for molecular interactions: hydrogen bonds; $\pi-\pi$ stacking; and hydrophobic interactions. The effect of structural modification on the inhibitory selectivity of phytochemical derivatives on CYP1A1, CYP1A2, and CYP1B1 help to elucidate which interactions determine the inhibitory ability of the compounds. There are similarities between the active sites of CYP1A2 and CYP1A1 which are in accordance with the overlapping substrate specificities of the two enzymes. However, the CYP1A1 substrates are generally of higher lipophilicity than those of CYP1A2. The reason lies in the more hydrophobic character of the CYP1A1 active site region (including the access channel) in comparison to CYP1A2 active site (Lewis et al., 1999). The differences in the structure of enzyme binding sites may determine the metabolism pathways of a substrate. With the use of computational docking the mechanism of E2 2-hydroxylation and 4-hydroxylation catalyzed by CYP1A1/2 and CYP1B1, respectively, were elucidated. CYP1A1 and CYP1A2 produced 2-OH-E2 and 4-OH-E2 in a ratio of $10: 1$; whereas CYP1B1 produces 2-OH-E2 and 4-OH-E2 in a ratio of $1: 3$ (Lee et al., 2003). The docking study suggests that CYP1A1 and CYP1A2 generate 2-OH-E2 rather than 4-OH-E2, and that CYP1B1 generates both 2-OH-E2 and 4-OH-E2. Particular amino acids residues for each CYP were identified as playing an important role in estradiol recognition (Itoh et al., 2010).

Several groups of phytochemicals were tested for affinity to active sites of CYP1 members. The first studied compounds were rutaecarpine derivatives. An alkaloid rutaecarpine preferentially inhibited CYP1A2 activity with $\mathrm{IC}_{50}$ value of $22 \mathrm{nM}$. However, 1-methoxyrutaecarpine and 1,2dimethoxyrutaecarpine were the most selective CYP1A2 inhibitors. Molecular modeling showed a good fitting of rutaecarpine and the active site of CYP1A2. Two hydrogen bonds between the keto- and N14-groups of rutaecarpine and the $\mathrm{Thr}^{208}$ and $\mathrm{Thr}^{473}$ residues of CYP1A2, respectively, were visualized with molecular modeling procedures. The C-ring moiety of rutaecarpine formed $\pi-\pi$ stacking interaction with the aromatic ring of $P e^{205}$ residue (Don et al., 2003).

Coumarin was shown to be a substrate of human CYPs, specifically: CYP1A1 and CYP1A2. Molecular modeling led to recognition and localization of the amino acid residues which interact with coumarin molecules resulting in the orientation of coumarin with 3,4 bond directly above the heme moiety. Coumarin 3,4-epoxide is produced and then rearranged to hydroxyphenylacetaldehyde, which can be further metabolized to toxic products. In the CYP1A1 active site, Ser113 forms a hydrogen bond with coumarin, while Phe ${ }^{205}$ and Phe 358 are responsible for aromatic $\pi-\pi$ stacking. In CYP1A2, Thr ${ }^{113}$ forms hydrogen bonds with coumarin, and Phe 205 is responsible for $\pi-\pi$ stacking (Lewis et al., 2006). However the different key residues take part in the interactions with coumarin, they determine the same site of metabolism, and in consequence, the pathway of coumarin metabolism is the same for both CYP1A1 and CYP1A2 .

7,8-benzoflavone ( $\alpha$-naphthoflavone) is a prototype flavonoid which has been used to examine the mechanism of action on P450 enzymes. Molecular modeling studies revealed that 7,8-naphthoflavone is positioned in a hydrophobic cavity of CYP1A2 next to the 
active site where it may cause a direct effect on substrate binding (Cho et al., 2003). Further studies with the use of molecular docking were aimed at methoxyflavonoids with a 2-3 double bond, which exerted strong inhibitory effect on CYP1 activities, particularly CYP1B1 (Takemura et al., 2010). The authors observed that the binding specificity of methoxyflavonoids is based on the interactions between the methoxy groups and specific CYP1s residues. For example, chrysoeriol and isorhamnetin fit well into the active site of CYP1B1, but do not fit into the active site of CYP1A2 and 1A1 because of steric collisions between the methoxy substituent of these methoxyflavonoids and Ser ${ }^{122}$ in CYP1A1 and Thr ${ }^{124}$ in CYP1A2. Androutsopoulos's group described molecular docking of several flavonoids with regard to their metabolism and inhibitory activity. The simulated binding orientation of the compounds tested was in accordance with the study of Takemura and coworkers (2010). Diosmetin and eupatorin are predicted to be oriented with ring-B over the prosthetic group so that $4^{\prime}$-methoxy group is at $\sim 4.5 \AA$ from the heme iron. The less substituted chrysin and acacetin also were shown to bind CYP1A1 with ring-B over the ironheme group. However, a lower number of interactions were found within the active site of CYP1A1 (Androutsopoulos et al., 2011).

To better characterize stilbenes as ligands of CYPs, we performed molecular docking by simulation of resveratrol and pterostilbene binding in active sites of CYP1A2 and CYP1B. Resveratrol and pterostilbene molecules were docked into the cavities of CYP1A2 (PDB code: 2hi4) and CYP1B1 (PDB code: $3 \mathrm{pm} 0$ ) with the use of the CDOCKER procedure implemented in Accelrys Discovery Studio 2.5.5. CDOCKER uses a CHARMm-based molecular dynamics (MD) scheme to dock ligands into a receptor binding site. For assigning receptor and ligand atom partial charges, we applied the charging rules used in the MMFF94 forcefield. Docked poses were scored by the negative value of CDOCKER energy for the -CDOCKER_ENERGY function, which include interaction energy and internal ligand energy: the higher positive value of -CDOCKER_ENERGY, the stronger affinity of a ligand to the binding site.

Our docking experiment showed that in the CYP1A2 active site, all possible poses of resveratrol can be grouped into two sets. This observation indicated that two binding modes are possible for resveratrol molecule. In mode A, represented by the pose with highest score, a resveratrol molecule is directed with $4^{\prime}-\mathrm{OH}$ group toward a heme (Fig. 3a). In mode B, the second ring with $3-\mathrm{OH}$ and $5-\mathrm{OH}$ substituents is situated in the vicinity of a prosthetic group (Fig. $3 b$ ). In both orientations, resveratrol binding is stabilized by $\pi-\pi$ stacking interactions, with phenyl ring of $\mathrm{Phe}^{226}$ (mode A), and with $\mathrm{Phe}^{226}$ and $\mathrm{Phe}^{260}$ (mode B). Contrary to resveratrol, a pterostilbene molecule was docked in the CYP1A2 active site only in one orientation with 4 '-OH group directed toward a heme (Fig. 3c). Pterostilbene binding was stabilized by $\pi-\pi$ interaction with an aromatic ring of Phe ${ }^{226}$. For a resveratrol molecule docked in the active site of CYP1B1, we also distinguished two binding modes. In contrast to CYP1A2, the highest scored pose corresponded to binding mode B. In both orientations (A and B), resveratrol was stabilized by two $\pi-\pi$ interactions between both of its rings and a phenyl ring of Phe ${ }^{231}$, and additionally by two hydrogen bonds with $\mathrm{Asn}^{265}$ and Asp ${ }^{333}$ in mode B, or Asn'265 and Asn 228 in mode A (Fig. 3d and 3e).

Similar to interaction with CYP1A2, a pterostilbene molecule represented only one type of orientation in the CYP1B1 cavity (Fig. 2f). The binding conformation with 4'-OH group close to a heme was stabilized by two $\pi-\pi$ stacking interactions with Phe ${ }^{231}$. In the case of 


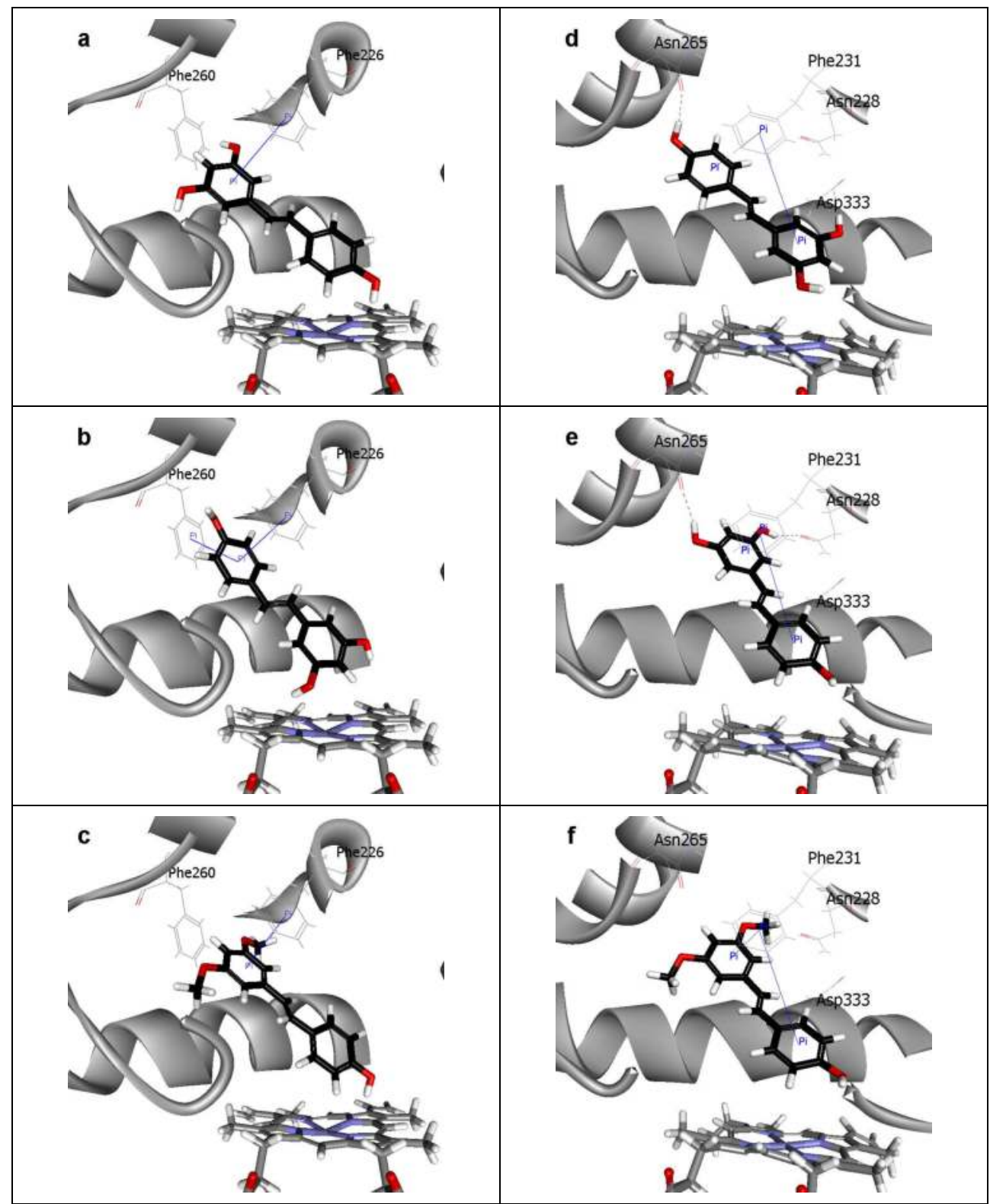

Fig. 3. Putative binding modes of resveratrol and pterostilbene in active sites of CYP1A2 (a c) and CYP1B1 $(\mathrm{d}-\mathrm{f})$ with key residues involved in $\pi-\pi$ stacking interactions and hydrogen bonds represented by solid blue lines and dashed blue lines, respectively. Heme molecule is at the bottom. CYP1A2 active site in complex with: (a) resveratrol in binding mode A, (b) resveratrol in mode $\mathrm{B},(\mathrm{c})$ pterostilbene. CYP1B1 active site in complex with: $(\mathrm{d})$ resveratrol in binding mode $B$, (e) resveratrol in mode $A,(f)$ pterostilbene. 
pterostilbene, which is a dimethoxy analogue of resveratrol, it is suggested that hydrophobic interactions might play a key role determining and stabilizing its docking orientation.

In studies of trans-resveratrol metabolism by human microsomal CYP1B1 enzyme (Potter et al., 2002), the authors observed formation of two metabolites, M1 and M2. The major metabolite M2 has been identified as piceatannol (3,4,3',5'-tetrahydroxystilbene), while 3,4,5,4'-tetrahydroxystilbene was proposed as the M1 product. More recent work (Piver et al., 2004) provided evidence that CYP1A2 is also engaged in the metabolism of transresveratrol to piceatannol and tetrahydroxystilbene M1. Our studies confirmed the possibility of two pathways of metabolism on the grounds of molecular docking analysis.

\section{Conclusion}

The finding of high affinity ligands among natural compounds for each of the CYP1 family enzymes will help to reveal more about enzyme specificity, providing a starting point for more extensive studies and improved predictive capabilities. Particularly, a selective inhibition against CYP1B1 that influences the chemopreventive properties of phytochemicals for E2 related breast cancer seems to be promising. There is a need for better characterization of potential chemopreventive/therapeutic agents in order to understand their abilities and limits to influencing numerous pathways leading to cancer development. Novel classes of anti-cancer drugs including those of plant origin are being developed that can target both drug-metabolizing enzymes and disease modifying pathways. Recently, interest in the combinatory effect of different phytochemicals is growing, with respect to the multi-targeted action of numerous components of a food matrix. Wenzel and co-workers found that metabolism of resveratrol present in beverages such as wine or grape juice is inhibited by other polyphenols due to competitive reactions with Phase -II enzymes, resulting in an increased concentration of the free form (Wenzel et al., 2005). It is suggested that an efficient chemoprevention strategy lies in the use of combinations of several chemopreventive and/or therapeutic agents which may exert multi-targeted action. In conclusion, the search for potent and selective CYP1A inhibitors appears to hold promise and should be continued with the use of novel computational techniques.

\section{References}

Aggarwal, B.B.; Kumar, A. \& Bharti, A.C. (2003). Anticancer potential of curcumin: preclinical and clinical studies. Anticancer Res., Vol. 23, No. 1A, (January-February 2003), pp. 363-398, ISSN 0250-7005

Andrieux, L.; Langouet, S.; Fautrel, A.; Ezan, F.; Krauser, J.A.; Savouret, J.F.; Guengerich, F.P.; Baffet, G. \& Guillouzo, A. (2004). Aryl hydrocarbon receptor activation and cytochrome P450 1A induction by the mitogen-activated protein kinase inhibitor UO126 in hepatocytes. Mol. Pharmacol., Vol. 65, No 4, (April 2004), pp. 934-943, ISSN 0026-895X

Androutsopoulos, V.P.; Papakyriakou, A.; Vourloumis, D. \& Spandidos, D.A. (2011). Comparative CYP1A1 and CYP1B1 substrate and inhibitor profile of dietary flavonoids. Bioorg. Med. Chem., Vol. 19, No. 9, (May 2011), pp. 2842-2849, ISSN 0968-0896

Appiah-Opong, R.; Commandeur, J.N.M.; van Vugt, B. \& Vermeulen, N.P.E. (2007). Inhibition of human recombinant cytochrome $\mathrm{P} 450$ s by curcumin and curcumin decomposition products. Toxicology, Vol. 235, No. 1-2, (June 2007), pp. 83-91, ISSN 0300-483X 
Appiah-Opong, R.; de Esch, I.; Commandeur, J.N.; Andarini M. \& Vermeulen, N.P. (2008). Structure-activity relationships for the inhibition of recombinant human cytochromes P450 by curcumin analogues. Eur. J. Med. Chem., Vol. 43, No. 8, (August 2008), pp. 1621-1631, ISSN 0223-5234

Badal, S.; Williams, S.A.; Huang, G.; Francis, S.; Vendantam, P.; Dunbar, O.; Jacobs, H.; Tzeng, T.J.; Gangemi, J. \& Delgoda, R. (2011). Cytochrome P450 1 enzyme inhibition and anticancer potential of chromene amides from Amyris plumieri. Fitoterapia, Vol. 82, No. 2, (March 2011), 230-236, ISSN 0367-326X

Beedanagari, S.R.; Bebenek, I.; Bui, P. \& Hankinson, O. (2009). Resveratrol inhibits dioxininduced expression of human CYP1A1 and CYP1B1 by inhibiting recruitment of the aryl hydrocarbon receptor complex and RNA polymerase II to the regulatory regions of the corresponding genes. Toxicol. Sci., Vol. 110, No. 1, (July 2009), pp. 6167, ISSN 1096-6080

Bode, A.M. \& Dong, Z. (2009). Cancer prevention research - then and now. Nature Rev. Cancer, Vol. 9, No. 7 (June 2009), pp. 508-516, ISSN 1474-175X

Bruno, R.D. \& Njar, V.C.O. (2007). Targeting cytochrome P450 enzymes: A new approach in anti-cancer drug development. Bioorg. Med. Chem., Vol. 15, No. 15 (August 2007), pp. 5047-5060, ISSN 0968-0896

Cai, Y.; Baer-Dubowska, W.; Ashwood-Smith, M.J.; Ceska, O.; Tachibana, S. \& DiGiovanni, J. (1996). Mechanism-based inactivation of hepatic ethoxyresorufin O-dealkylation activity by naturally occurring coumarins. Chem. Res. Toxicol., Vol. 9, No. 4, (June 1996), pp. 729-736, ISSN 0893-228X

Cai, Y.; Baer-Dubowska, W.; Ashwood-Smith, M. \& DiGiovanni, J. (1997). Inhibitory effects of naturally occurring coumarins on the metabolic activation of benzo[a]pyrene and 7,12-dimethylbenz[a]anthracene in cultured mouse keratinocytes. Carcinogenesis, Vol. 18, No. 8 (August 1997), pp. 215-222, ISSN 0143-3334

Canistro, D.; Bonamassa, B.; Pozzetti, L.; Sapone, A.; Abdel-Rahman, S.Z.; Biagi, G.L. \& Paolini, M., (2009). Alteration of xenobiotic metabolizing enzymes by resveratrol in liver and lung of CD1 mice. Food Chem. Toxicol. Vol. 47, No. 2, (February 2009), pp. 454-461, ISSN 0278-6915

Casper, R.F.; Quesne, M.; Rogers, I.M.; Shirota, T.; Jolivel, A.; Milgrom, E. \& Savouret, J.F. (1999). Resveratrol has antagonist activity on the aryl hydrocarbon receptor: implications for prevention of dioxin toxicity. Mol. Pharmacol. Vol. 56, No. 4, (October 1999), pp. 784-790, ISSN 0026-895X

Castro, D.J.; Baird, W.M.; Pereira, C.B.; Giovanini, J.; Lohr, C.V.; Fischer, K.A.; Yu, Z.; Gonzalez, F.J.; Krueger, S.K. \& Williams, D.E. (2008). Fetal mouse Cyp1b1 and transplacental carcinogenesis from maternal exposure to dibenzo(a,1)pyrene. Cancer Prev. Res. (Phila), Vol. 1, No. 2, pp. 128-134, ISSN 1940-6207

Chang, T.K.H.; Lee, W.B. \& Ko, H.H. (2000). Trans-resveratrol modulates the catalytic activity and mRNA expression of the procarcinogens-activating human cytochrome P450 1 B1. Can. J. Physiol. Pharmacol., Vol. 78, No. 11 (November 2011), pp. 874-881, ISSN 0008-4212

Chang, T.K.H.; Chen, J. \& Lee, W.B. (2001). Differential inhibition and inactivation of human CYP1 enzymes by trans-resveratrol: evidence for mechanism-based inactivation of CYP1A2. J. Pharmacol. Exp. Ther., Vol. 299, No. 3, (December 2001), pp. 874-882, ISSN 0022-3565

Chang, T.K.H.; Chen, J. \& Yu, C.-T. (2007). In vitro inhibition of rat CYP1A1 and CYP1A2 by piceatannol, a hydroxylated metabolite of trans-resveratrol. Drug Metab. Lett., 1, 1, (January 2007), pp. 13-16, ISSN 1872-3128 
Chaudhary, A. \& Willett, K.L. (2006). Inhibition of human cytochrome CYP1 enzymes by flavonoids of St. John's wort. Toxicology, Vol. 217, No. 2-3, (January 2006), pp. 194205, ISSN 0300-483X

Chen, Z.H.; Hurh, Y.J.; Na, H.K.; Kim, J.H.; Chun, Y.J.; Kim, D.H.; Kang, K.S.; Cho, M.H. \& Surh, Y.J. (2004). Resveratrol inhibits TCDD-induced expression of CYP1A1 and CYP1B1 and catechol estrogen-mediated oxidative DNA damage in cultured human mammary epithelial cells. Carcinogenesis, Vol. 25, No. 10, (October 2004), pp. 2005-2013, ISSN 0143-3334

Cho, U.S.; Park, E.Y.; Dong, M.S.; Park, B.S.; Kim, K. \& Kim, K.H. (2003). Tight-binding inhibition by $\alpha$-naphthoflavone of human cytochrome P450 1A2. Biochim. Biophys. Acta, Vol. 1648, No. 1-2, (May 2003), pp. 195-202, ISSN 0006-3002

Chun, Y.J.; Kim, M.Y. \& Guengerich, F.P. (1999). Resveratrol is a selective human cytochrome P450 1A1 inhibitor. Biochem. Biophys. Res. Commun., Vol. 262, No. 1, (August 2999), pp. 20-24, ISSN 0006-291X

Chun, Y.J.; Ryu, S.Y.; Jeong, T.C. \& Kim, M.Y. (2001a). Mechanism-based inhibition of human cytochrome P450 1A1 by rhapontigenin. Drug Metab. Dispos., Vol. 29, No. 4, (April 2001), pp. 389-393, ISSN 0090-9556

Chun, Y.J.; Kim, S.; Kim, D.; Lee, S.K. \& Guengerich, F.P. (2001b). A new selective and potent inhibitor of human cytochrome P450 1B1 and its application to antimutagenesis. Cancer Res., Vol. 61, No. 22, (November 2001), pp. 8164-8170, ISSN 0008-5472

Ciolino, H.P. \& Yeh, G.C. (1999). Inhibition of aryl hydrocarbon-induced cytochrome P-450 1A1 enzyme activity and CYP1A1 expression by resveratrol. Mol. Pharmacol., Vol. 56, No. 4, (October 1999), pp. 760-767, ISSN 0026-895X

Ciolino, H.P.; Daschner, P.J. \& Yeh, G.C. (1998). Resveratrol inhibits transcription of CYP1A1 in vitro by preventing activation of the aryl hydrocarbon receptor. Cancer Res., Vol. 58, No. 24, (December 1998), pp. 5707-5712, ISSN 0008-5472

de Medina, P.; Casper, R.; Savouret, J.-F. \& Poirot, M. (2005). Synthesis and biological properties of new stilbene derivatives of resveratrol as new selective aryl hydrocarbon modulators. J. Med. Chem., Vol. 48, No. 1, (January 2005), pp. 287-291, ISSN 1520-4804

Don, M.-J.; Lewis, D.F.V.; Wang, S.-Y.; Tsai, M.-W. \& Ueng, Y.F. (2003). Effect of structural modification on the inhibitory selectivity of rutaecarpine derivatives on human CYP1A1, CYP1A2, and CYP1B1. Bioorg. Med. Chem. Lett., Vol. 13, No.15, (August 2003), pp. 2535-2538, ISSN 0960-894X

Gaudineau, C.; Beckerman, R.; Welbourn, S. \& Auclair, K. (2004). Inhibition of human P450 enzymes by multiple constituents of the Ginkgo biloba extract. Biochem. Biophys. Res. Commun., Vol. 318, No. 4, (June 2004), pp. 1072-1078, ISSN 0006-291X

Gerhauser, C.; Klimo, K.; Heiss, E.; Neumann, I.; Gamal-Eldeen, A.; Knauft, J.; Liu, G.Y.; Sitthimonchai, S. \& Frank, N. (2003) Mechanism-based in vitro screening of potential cancer chemopreventive agents. Mutat. Res., Vol. 523-524, (FebruaryMarch 2003), pp. 163-172, ISSN 0027-5107

Gonzalez, F.J. (2002).Transgenic models in xenobiotic metabolism and toxicology. Toxicology, Vol. 181-182 (December 2002), pp. 237-239, ISSN 0300-483X

Goswami, S.K. \& Das, D.K. (2009). Resveratrol and chemoprevention. Cancer Lett., Vol. 284, No. 1, (October 2009), pp. 1-6, ISSN 0304-3835

Guengerich, F.P.; Chun, Y-J.; Kim, D.; Gillam, E.M.J. \& Shimada, T. (2003). Cytochrome P450 1B1: a target for inhibition in anticarcinogenesis strategies. Mutat. Res., Vol. 523-524, (February-March), pp. 173-182, ISSN 0027-5107 
Itoh, T.; Takemura, H.; Shimoi, K. \& Yamamoto, K. (2010). A 3D model of CYP1B1 explains the dominant 4-hydroxylation of estradiol. J.Chem. Inf. Model., Vol. 50, No. 6, (June 2010), pp. 1173-1178, ISSN 1549-9596

Jang, M.; Cai, L.; Udeani, G.O.; Slowing, K.V.; Thomas, C.F.; Beecher, C.W.W.; Fong, H.H.S.; Farnsworth, N.R.; Kinghorn, A.D.; Mehta, R.G.; Moon, R.C. \& Pezzuto, J.M. (1997). Cancer chemopreventive activity of resveratrol, a natural product derived from grapes, Science, Vol. 275, No. 5297, (January 1997), pp. 218-220, ISSN 0036-8075

Kim, S.; Ko, H.; Park, J.E.; Jung, S.; Lee, S.K. \& Chun, Y.J. (2002). Design, synthesis and discovery of novel trans-stilbene analogues as potent and selective human cytochrome P450 1 B1 inhibitors. J. Med. Chem., Vol. 45, No. 1, (January 2002), pp. 160-164, ISSN 1520-4804

Kisselev, P.; Schunck, W.H.; Roots, I. \& Schwarz, D. (2005). Association of CYP1A1 polymorphism with differential metabolic activation of 17- $\beta$-estradiol and estrone. Cancer Res., Vol. 65, No. 7, (April 2005), pp. 2972-2978, ISSN 0008-5472

Kuhnau, J. (1976). A class of semiessential food components: their role in human nutrition. World Rev. Nutr. Diet, Vol. 24, pp. 117-191, ISSN 0084-2230

Lamb, D.C.; Waterman, M.R.; Kelly, S.L. \& Guengerich, F.P. (2007). Cytochromes P450 and drug discovery. Curr. Opin. Biotech., Vol. 18, No. 6, (December 2007), pp. 504-512, ISSN 0958-1669

Lee, A.J.; Cai, M.X.; Thomas, P.E.; Conney, A.H. \& Zhu, B.T. (2003). Characterization of the oxidative metabolites of $17 \beta$-estradiol and estrone formed by 15 selectively expressed human cytochrome p450 isoforms. Endocrinology, Vol. 144, No. 8, (August 2003), pp. 3382-3398, ISSN 0013-7227

Lewis, D.F.V. (1997). Quantitative structure - activity relationships in substrates, inducers and inhibitors of cytochrome P450 (CYP1). Drug Metab. Rev., Vol. 29, No. 3, (August 1997), pp. 589-650, ISSN 0360-2532

Lewis, D.F.V.; Lake, B.G.; George, S.G.; Dickins, M.; Eddershaw, P.J.; Tarbit, M.H.; Beresford, A.P.; Goldfarb, P.S. \& Guegerich, F.P. (1999). Molecular modeling of CYP1 family enzymes CYP1A1, CYP1A2, CYP1A6 and CYP1B1 based on sequence homology with CYP102. Toxicology, Vol. 139, No. 1-2, (November 1999), pp. 53-79, ISSN 0300-483X

Lewis, D.F.V.; Ito, Y. \& Lake, B.G. (2006). Metabolism of coumarin by human P450s: A molecular modeling study. Toxicol. in vitro, Vol. 20, No 2, (March 2006), pp. 256-264, ISSN 0887-2333

Liehr, J.G. \& Ricci, M.J. (1996). 4-Hydroxylation of estrogens as marker of human mammary tumors. Proc. Natl. Acad. Sci. U.S.A. , Vol. 93, No. 8, (April 1996), pp. 3294-3296, ISSN 0027-8424

MacPherson, L. \& Matthews, J. (2010). Inhibition of aryl hydrocarbon receptor-dependent transcription by resveratrol or kaempferol is independent of estrogen receptor $\alpha$ expression in human breast cancer cells. Cancer Lett., Vol. 299, No. 2, (December 2010), pp. 119-129, ISSN 0304-3835

Mc Fadyen, M.C. \& Murray, G.I. (2005). Cytochrome P450 1B1: a novel anticancer therapeutic target. Future Oncol. 1, No. 2, (April 2005), pp. 259-263, ISSN 1479-6694

Mikstacka, R.; Przybylska, D.; Rimando, A.M. \& Baer-Dubowska, W. (2007). Inhibition of human recombinant cytochromes P450 CYP1A1 and CYP1B1 by trans-resveratrol metyl ethers. Mol. Nutr. Food Res., Vol. 51, No. 5, (May 2007), pp. 517-524, ISSN 1613-4125

Mikstacka, R.; Rimando, A.M.; Szalaty, K.; Stasik, K. \& Baer-Dubowska, W. (2006). Effect of natural analogues of trans-resveratrol on cytochromem P450 1A2 and 2E1 catalytic activities. Xenobiotica, Vol. 36, No. 4, (April 2006), pp. 269-285, ISSN 0049-8254 
Mikstacka, R.; Baer-Dubowska, W.; Wieczorek, M. \& Sobiak, S. (2008). Thiomethylstilbenes as inhibitors of CYP1A1, CYP1A2 and CYP1B1 activities. Mol. Nutr. Food Res., Vol. 52, No. S1, (June 2008), pp. S77-S83, ISSN 1613-4125

Oetari, S.; Sudibyo, M.; Commandeur, J.N.M.; Samhoedi, R. \& Vermeulen, N.P.E. (1996). Effects of curcumin on cytochrome P450 and glutathione-S-transferase activities in rat liver. Biochem. Pharmacol., Vol. 51, No. 1, (January 1996), pp. 39-45, ISSN 0006-2952

Piver, B.; Berthou, F.; Dreano, Y. \& Lucas, D. (2003). Differential inhibition of human cytochrome P450 enzymes by $\varepsilon$-viniferin, the dimer of resveratrol: comparison with resveratrol and polyphenols from alcoholized beverages. Life Sci., Vol. 73, No. 9, (July 2003), pp. 1199-1213, ISSN 0024-3205

Piver, B.; Fer, M.; Vitrac, X.; Merillon, J.-M.; Dreano, Y.; Berthou, F. \& Lucas, D. (2004). Involvment of cytochrome P450 1A2 in the biotransformation of trans-resveratrol in human liver microsomes. Biochem. Pharmacol., Vol. 68, No. 4, (August 2004), pp. 773-783, ISSN 0006-2952

Potter, G.A.; Patterson, L.H.; Wanogho, E.; Perry, P.J.; Butler, P.C.; Iljaz, T.; Ruparelia, K.C.; Lamb, J.H.; Farmer, P.B.; Stanley, L.A. \& Burke, M.D. (2002). The cancer preventive agent resveratrol is converted to the anticancer agent piceatannol by the cytochrome $\mathrm{P} 450$ enzyme CYP1B1. Br. J. Cancer, Vol. 86, No. 5, (March 2002), pp. 774-778, ISSN 0007-0920

Rendic, S. \& Di Carlo, F.J. (1997). Human cytochromes P450 enzymes: a status report summarizing their reactions, substrates, inducers, and inhibitors. Drug Metab. Rev., Vol. 29, No. 1-2, (February-May 1997), pp. 413-580, ISSN 0360-2532

Revel, A.; Raanani, H.; Younglai, E.; Xu, J.; Rogers, I.; Han, R.; Savouret, J.F. \& Casper, R.F. (2003). Resveratrol, a natural aryl hydrocarbon receptor antagonist, protects lung from DNA damage and apoptosis caused by benzo[a]pyrene. J. Appl. Toxicol., Vol. 23, No. 4, (July-August 2003), pp. 255-261, ISSN 0260-437X

Rimando, A.M.; Cuendet, M.; Desmarchelier, C.; Mehta, R.G.; Pezzuto, J.M. \& Duke, O.D. (2002). Cancer chemopreventive and antioxidant activities of pterostilbene, a naturally occurring analogue of resveratrol. J. Agric. Food Chem., Vol. 50, No. 12, (June 2002), pp. 3453-3457, ISSN 0021-8561

Rimando, A.M.; Kalt, W.; Magee, J.B.; Dewey, J. \& Ballington, J.R. (2004). Resveratrol, pterostilbene, and piceatannol in Vaccinium berries. J. Agric. Food Chem., Vol. 52, No. 15, (July 2004), pp. 4713-4719, ISSN 0021-8561

Rimando, A.M. \& Suh, N. (2008). Biological/chemopreventive activity of stilbenes and their effect on colon cancer. Planta Med., Vol. 74, No. 13, (October 2008), pp. 1635-1643, ISSN 0032-0943

Rodeiro, I.; Donato, M.T.; Jimenez, N.; Garrido, G.; Molina-Torres, J.; Menendez, R.; Castell, J.V. \& Gomez-Lechon, M.J. (2009). Inhibition of human P450 enzymes by natural extracts used in traditional medicine. Phytother. Res., Vol. 23, No. 2, (February 2009), pp. 279-282, ISSN 0951-418X

Ryu, S.-D. \& Chung, W.-G. (2003). Induction of the procarcinogen-activating CYP1A2 by a herbal dietary supplement in rats and humans. Food Chem. Toxicol., Vol. 41, No. 6, (June 2003), pp. 861-866, ISSN 0278-6915

Schwarz, D. \& Roots, I. (2003). In vitro assessment of inhibition by natural polyphenols of metabolic activation of procarcinogens by human CYP1A1. Biochem. Biophys. Res. Commun., Vol. 303, No. 3, (April 2003), pp. 902-907, ISSN 0006-291X

Schwarz, D.; Kisselev, P.; Schunck, W.-H. \& Roots, I. (2011). Inhibition of 17ß-estradiol activation by CYP1A1: genotype- and regioselective inhibition by St. John's Wort 
and natural polyphenols. Biochim. Biophys. Acta, Vol. 1814, No. 1, (January 2011), pp. 168-174, ISSN 0006-3002

Sporn, M.B. \& Liby, K.T. (2005) Cancer chemoprevention: scientific promise, clinical uncertainty. Nature Clinical Practise Oncology, Vol. 2, No. 10, (October 2005), pp. 518525, ISSN 1743-4254

Swanson, H.I.; Njar, W.C.O.; Yu, Z.; Castro, D.J.; Gonzalez, F.J.; Williams, D.E.; Huang, Y.; Kong, A.-N. T.; Doloff, J.C.; Ma, J.; Waxman, D.J. \& Scott, E.E. (2010). Targeting drug-metabolizing enzymes for effective chemoprevention and chemotherapy. Drug Metab. Dispos., Vol. 38, No. 4, (April 2010), pp. 539-544, ISSN 0090-9556

Szaefer, H.; Cichocki, M.; Brauze, D. \& Baer-Dubowska, W. (2004). Alteration in phase I and II enzyme activities and polycyclic aromatic hydrocarbon-DNA adduct formation by plant phenolics in mouse epidermis. Nutr. Cancer Vol. 48, No. 1, (January 2004), pp. 70-77, ISSN 0163-5581

Szekeres, T.; Fritzer-Szekeres, M.; Saiko, P. \& Jager, W. (2010). Resveratrol and resveratrol analogues - structure-activity relationship. Pharm. Res., 27, 6, (March 2010), pp. 1042-1048, ISSN 0724-8741

Takemura, H.; Itoh, T.; Yamamoto, K.; Sakakibara, H. \& Shimoi, K. (2010). Selective inhibition of methoxyflavonoids on human CYP1B1 activity. Bioorg. Med. Chem., Vol. 18, No. 17, (September 2010), pp. 6310-6315, ISSN 0968-0896

Thapliyal, R. \& Maru, G.B. (2001). Inhibition of cytochrome P450 isozymes by curcumins in vitro and in vivo. Food Chem. Toxicol., Vol. 39, No. 6, (June 2001), pp. 541-547, ISSN 0278-6915

Walle, T.; Hsieh, F.; DeLegge, M.H.; Oatis, J.E.,Jr. \& Walle, U.K. (2004). High absorption but very low bioavailability of oral resveratrol in humans. Drug Metab. Dispos., Vol. 32, No. 12, (December 2004), pp. 1377-1382, ISSN 0090-9556

Walle, U.K. \& Walle, T. (2007). Novel methoxylated flavone inhibitors of cytochrome P450 1B1 in SCC9 human oral cancer cells. J. Pharm. Pharmacol., Vol. 59, No. 6, (June 2007), pp. 857-862, ISSN 0022-3573

Wattenberg, L.W. (1985). Chemoprevention of cancer. Cancer Res., Vol. 45, No. 1, (January 1985), pp. 1-8, ISSN 0008-5472

Wenzel, E.; Soldo, T.; Erbersdobler, H. \& Somoza, V. (2005). Bioactivity and metabolism of trans-resveratrol orally administered to Wistar rats. Mol. Nutr. Food Res., Vol. 49, No. 5, (May 2005), pp. 482-494, ISSN 1613-4125

William, W.N., Jr.; Heymach, J.V.; Kim, E.S. \& Lippman, S.M. (2009). Molecular targets for cancer chemoprevention. Nat. Rev. Drug Discov., Vol. 8, No. 3, (March 2009), pp. 213-225, ISSN 1474-1776

Yamaori, S.; Kushihara, M.; Yamamoto, I. \& Watanabe, K. (2010). Characterization of major phytocannabinoids, cannabidiol and cannabinol, as isoform selective and potent inhibitiors of human CYP1 enzymes. Biochem. Pharmacol., Vol. 79, No. 11, (June 2010), pp. 1691-1698, ISSN 0006-2952

Zhai, S.; Dai, R.; Friedman, F.K. \& Vestal, R.E. (1998). Comparative inhibition of human cytochromes P450 1A1 and 1A2 by flavonoids. Drug Metab. Dispos., Vol. 26, No. 10, (October 1998), pp. 989-992, ISSN 0090-9556 


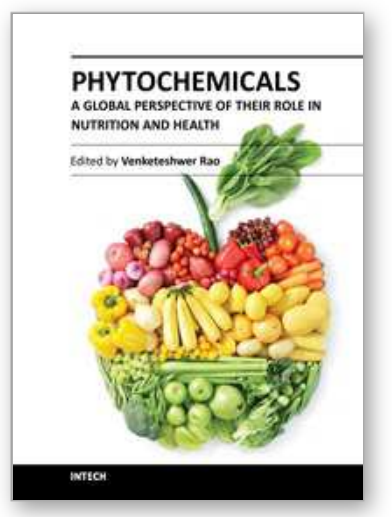

\author{
Phytochemicals - A Global Perspective of Their Role in Nutrition \\ and Health \\ Edited by Dr Venketeshwer Rao
}

ISBN 978-953-51-0296-0

Hard cover, 538 pages

Publisher InTech

Published online 21, March, 2012

Published in print edition March, 2012

Phytochemicals are biologically active compounds present in plants used for food and medicine. A great deal of interest has been generated recently in the isolation, characterization and biological activity of these phytochemicals. This book is in response to the need for more current and global scope of phytochemicals. It contains chapters written by internationally recognized authors. The topics covered in the book range from their occurrence, chemical and physical characteristics, analytical procedures, biological activity, safety and industrial applications. The book has been planned to meet the needs of the researchers, health professionals, government regulatory agencies and industries. This book will serve as a standard reference book in this important and fast growing area of phytochemicals, human nutrition and health.

\title{
How to reference
}

In order to correctly reference this scholarly work, feel free to copy and paste the following:

Renata Mikstacka, Zbigniew Dutkiewicz, Stanisław Sobiak and Wanda Baer-Dubowska (2012). The Inhibitory Effect of Natural Stilbenes and Their Analogues on Catalytic Activity of Cytochromes P450 Family 1 in Comparison with Other Phenols - Structure and Activity Relationship, Phytochemicals - A Global Perspective of Their Role in Nutrition and Health, Dr Venketeshwer Rao (Ed.), ISBN: 978-953-51-0296-0, InTech, Available from: http://www.intechopen.com/books/phytochemicals-a-global-perspective-of-their-role-in-nutrition-andhealth/the-inhibitory-effect-of-natural-stilbenes-and-their-analogs-on-catalytic-activity-of-cytochromes-p4

\section{INTECH}

open science | open minds

\author{
InTech Europe \\ University Campus STeP Ri \\ Slavka Krautzeka 83/A \\ 51000 Rijeka, Croatia \\ Phone: +385 (51) 770447 \\ Fax: +385 (51) 686166 \\ www.intechopen.com
}

\author{
InTech China \\ Unit 405, Office Block, Hotel Equatorial Shanghai \\ No.65, Yan An Road (West), Shanghai, 200040, China \\ 中国上海市延安西路65号上海国际贵都大饭店办公楼 405 单元 \\ Phone: +86-21-62489820 \\ Fax: +86-21-62489821
}


(C) 2012 The Author(s). Licensee IntechOpen. This is an open access article distributed under the terms of the Creative Commons Attribution 3.0 License, which permits unrestricted use, distribution, and reproduction in any medium, provided the original work is properly cited. 